\title{
The Happiness Atmosphere in Classroom as Medium of Process Foreign Language Teaching
}

\author{
Mislawi Yadi \\ English Education, Sosial and humaniora, University of Ibrahimy \\ Email Correspondence : mislawiyadi.unib@gmail.com
}

ART ICLE INF O

Keywords:

The Happiness Atmosphere

Classroom Management

Foreign Language Teaching

\section{Article History:}

Received : 25 December 2021

Accepted : 05 February 2022

Published : 14 February 2022

\section{A B S T R A C T}

This study aims to determine the results of the teaching process in the classroom with the approach and design of learning happiness atmosphere in classroom which aims to increase mastery of a foreign language (English). This study used a qualitative descriptive method with data collection stages such as data collection steps including setting research boundaries, collecting information through observation, structured (or semi-structured) interviews, documents, visual materials, documenting the results of information in the field. The object of this research ware semester I students who toke speaking I courses at University of Ibrahimy. The stages and teaching in this class were used multiple methods in the stimulus so that students feel happy and happy in class. The research was used student-focused learning approach (student center). The learning model applied were CTL, Communicative approach, feedback review, discussion and natural learning. In the process of learning foreign language mastery in class, students were allowed used bilingual when having difficulty in vocabulary, students were allowed to directly ask their friends when they have difficulties and other friends were advised to provide feedback on their friends' questions, The final results obtained from the learning process with the application of the happiness atmosphere in the classroom turned out to be very positive results and the students were happy, accustomed to the teaching process and continued to apply learning theory to achieve appropriate success. 


\section{Introduction}

In this modern learning tools and supporting applications in technological advances development. However, social life plays a very confusing role to student learning behavior in achieving educational goals that lead to achievement targets. The impact of social media, gadgets, and online game applications were very time-consuming for students. Continuing education is an important factor and encourages continuing to advance and compete so that formal and nonformal education does not become a last resort. Students now prefer to linger in front of a computer / cellphone screen without feeling much time wasted just for a game and virtual life. The world has become a global village and used of technology has made it a smaller world through social media and how it changes instruction. This original study is among the few that have conducted focused investigations to uncover the relationship between the positive and negative characteristics of social media and student learning attitudes for the next study's education. However, it becomes a big problem when this is allowed. Currently, formal and face-to-face learning is starting to gradually shift to the world of the web, this becomes a serious problem when students are facilitated by the time and place to linger in cyberspace. Constructive and negative factors that impact on students' minds and how this helps students to share positive and negative aspects with others. It is increasingly seen that social networking sites and their applications provide enormous benefits and risks for students and their implications for psychological adjustment or student learning behavior are not well understood

Awareness of high-needs students classroom teachers meets daily with a wide range of students. In general, 12-22 percent of all students in schools suffer from mental, emotional, or behavioral disorders, and relatively few receive mental health services, The Association of School Counselors notes that 18 percent of students have special needs and require exceptional intervention and care that goes beyond the typical resources available in the classroom, Severe, teachers with effective classroom management skills are aware of the high needs of students and have a repertoire of specialized techniques to meet some of their needs (Marzano \& Marzano, 2003).

What are the stages and implementation of The Happiness atmosphere in the classroom as a medium of the foreign language learning process? What are the results of implementing The Happiness atmosphere in classroom as medium process of foreign language teaching? The purpose of this research were to apply the Happiness atmosphere in classroom as medium process of learning foreign language teaching and to find out the results of implementing The Happiness atmosphere in classroom as medium process of learning foreign language on the mastery of foreign languages in the classroom.

\section{Methods}

In this study, using a data collection and analysis approach through a qualitative descriptive procedure. In this qualitative procedure, it is identical to descriptive data in the form of unique steps in analyzing data, and utilizing multiple strategies in the analysis,(Creswell \& Creswell, 2017). The concept of this research has a very in-depth elaboration through descriptions and data. This is very possible in the strategy of the investigation as well as the method of collection and analysis.

Data collection steps include setting research boundaries, collecting information through unstructured (or semi-structured) observation and interviews, documents, visual materials, and documenting the results of information in the field, the data is obtained, then analyzed in the form of an in-depth description and elaboration (Creswell \& Creswell, 2017). 


\section{Result}

Based on the results of interviews and questionnaires given to students, it shows that the implementation of a happy atmosphere in the classroom can help students' abilities in developing English language skills, we can see this from the results of interviews and questionnaires given to students during the learning process In the early stages of applying some basic principles in the classroom, the second during exploration of the learning process, the researcher did not position himself as a judge of students, but as a study partner who was there and continues to accompany students when in difficult or happy situations. The researcher was aware of the students' first and second language. Teaching should be appropriate to the student's level of proficiency in both languages. we have to consider students cultural and family experiences when planning teaching and assessment, . Then, the consequences of it was applied to the field of language teaching would be clearly seen when students keep trying and keep trying in verbal forms such as conversation, communication, monologue and the description of the description that continues to be developed naturally in a better position to provide information and answers that were quite balanced from some of the questions asked. Making fun of a wrong answer was not accepted, and a norm of "mistake tolerance" was ratified, (Kinneging, 2000). About the lesson described but about any subject matter in English. This happiness process really helps students' mindsets, especially when they were in class position when they felt comfortable, their souls and feelings controlled and of course, the teaching targets achieved easily.

\section{Discussion}

In this study, the position of lecturer as a supervisor, coach, drafter, and observer at the same time becomes a researcher in the classroom. At the first meeting, the lecturer gave an overview and explanation of the theoretical framework for learning and classroom settings, explaining teaching methods and teaching models such as: CTL, audiovisual, communicative approach, feedback review, discussion, inquiry, presentation, and natural learning. The issue of teaching media and questions related to effective learning was important part of the current debate on language education and policy education planning in Hong Kong (Ping \& Ng, 2007). Learning theory and practice in the classroom, the position of students as objects and subjects in the application of this learning process. By involving students as subjects in this application to make it easier in class arrangements, materials and mastery of the atmosphere of learning conditions.

In the learning process, the researcher monitored the emotional relationships of students in the classroom. The teacher-student relationship were effective or not in the classroom, the teacher's personality relationship with students who viewed teacher as a friend. The most effective teacher-student relationship were characterized by teacher behavior that shows a level of dominance. that was in accordance with the level of cooperation who realizes that students need more (Marzano \& Marzano, 2003) Usually learning in class is identical to lecturing, appointing students to class, giving assignments and being closely monitored so that students become stiff, not free, want to quickly get out of the room and play Therefore, researcher work with students to create a learning atmosphere in the classroom to be meaningful, memorable and free from the shackles of anxiety which in the end the learning objectives achieved, The problem-based learning model with an inquiry approach was able to train process skills and involve students to solve a problem through the stages of the scientific method this study aims to measure the increase in mastery of concepts and skills (Prima \& Kaniawati, 2011)

Conceptualization is related to planning the application which refers to background knowledge, knowledge of the topic, about conversational situations, and knowledge of discourse 
patterns. The draftsman includes a 'monitor', which checks everything that happens in the interaction to ensure that the communication goes according to plan. It allowed for self-correcting for expressions, grammar, and pronunciation. After conceptualizing, the formulator found words and phrases to express meaning, then students were taught to sort them and enter the appropriate grammatical markers. Also, prepare the sound pattern of the words to be used. Second language learning errors or foreign language errors in pronunciation were very common because they involve sound switching between words that were separated from each other. Pronunciation in the form of words should be prepared before pronunciation. The third process was articulation. The process of language articulation involved the motor control of organs. On pronunciation in English lips, tongue, teeth, palate alveolus, velum, glottis, oral cavity, and breath. Self-monitoring was concerned with the ability of language used to identify and correct their own mistaken.

When students were faced with linguistic criteria that were objective or required to be structurally correct, students found it difficult to develop and depressed in the learning process. So that in class the lecturer told to students not to focus on grammar, pronunciation, and dialect of the speaker. Teaching spoken English in EFL classes requires students to learn English in their own cultural environment without using their target language in real situations,(Talley \& Hui-Ling, 2014). In this case, the researcher gave students the freedom to inquiry and adapt to existing abilities. The lecturer's statement was a great source of strength and motivation for students, this policy was a lecturer's policy in supporting students' creativity in learning foreign languages and was a form of love and trust that had been built during the learning process in class.

The final results obtained from the learning process with the application of the happy atmosphere in the classroom turned out very positive results and students were happy, accustomed to the teaching process and continued to apply learning theory to achieve appropriate success, as well as users of audio-visual learning as an effort to match student language. On the speaker's standard language style. Students gain confidence, courage, and the ability to think calmly and clearly during group discussions. They said that when asked by using a questionnaire, they answered that it was not as difficult as imagined. Such as the ability to play golf successfully and the ability to develop his abilities because he often optimizes his training abilities (Carnegie, 2017) So it is very important for students to continue to be given encouragement, strengthen trust and make the learning atmosphere in the classroom more comfortable, friendly, and less formal. The class atmosphere that students want is a neutral atmosphere and mutual trust in each other and passion about being together. There were great motivation and encouragement from the teacher and teacher as a friend, which has the potential to improve skills in learning foreign languages in the classroom.

\section{Conclusion}

In this study, several important factors need to be considered, such as how to teach students, learning models and theories, classroom readiness and management that supports, and students' readiness to follow the teaching agenda in the classroom. The happy nuance tends to allow students to master foreign languages quickly and concept involvement of lecturers and students harmonization greatly determines success in the speaking class. The results of this study are that using a happy atmosphere in class can increase the enthusiasm for learning and be able to improve the results of mastering a foreign language (English) Students.

\section{Acknowledgments}


Expressions of gratitude to all lecturers who have helped in writing this article, many things have been done by fellow lecturers who have supported from the beginning of the research, the research process to the final research report. I would like to thank all university staff who have given, did the research in the classroom which during the process they helped a lot in the implementation of this research. I say thank a lot to the head of the English study program who guided us in the preparation of the final research report so that in the end this article can be published.

\section{References}

Carnegie, D. (2017). How to develop self-confidence and influence people by public speaking. Simon and Schuster.

Creswell, J. W., \& Creswell, J. D. (2017). Research design: Qualitative, quantitative, and mixed methods approaches. Sage publications.

Kinneging, A. A. M. (2000). Het conservatisme: kritiek van de Verlichting en de moderniteit. Philosophia Reformata, 65(2), 126-153.

Marzano, R. J., \& Marzano, J. S. (2003). The key to classroom management. Educational Leadership, 61(1), 6-13.

Ping, F., \& Ng, D. (2007). Medium and learning in Chinese and English in Hong Kong classrooms. Language Policy, 6(1), 163-183.

Prima, E. C., \& Kaniawati, I. (2011). Penerapan model pembelajaran problem based learning dengan pendekatan inkuiri untuk meningkatkan keterampilan proses sains dan penguasaan konsep elastisitas pada siswa SMA. Jurnal Pengajaran MIPA, 16(1), 179-184.

Talley, P. C., \& Hui-Ling, T. (2014). Implicit and explicit teaching of English speaking in the EFL classroom. International Journal of Humanities and Social Science, 4(6), 38-45. 